\title{
Communication
}

\section{Geographic Distribution of Ehrlichia canis TRP Genotypes in Brazil}

\author{
Isis Indaiara Gonçalves Granjeiro Taques ${ }^{1}$, Amanda Noeli Silva Campos ${ }^{1}$, \\ Mayara Lima Kavasaki ${ }^{1}$, Sayanne Luns Hatum de Almeida ${ }^{2}$ and Daniel Moura de Aguiar $1, * \mathbb{D}$ \\ 1 Laboratory of Virology and Rickettsial Infections, Veterinary Hospital, Federal University of Mato Grosso, \\ Av. Fernando Correa da Costa 2367, Cuiabá 78090-900, Brazil; isis_indaiara@hotmail.com (I.I.G.G.T.); \\ amanda.noeli@hotmail.com (A.N.S.C.); mayarakawa@gmail.com (M.L.K.) \\ 2 Laboratory of Parasitology and Parasitic Diseases, Veterinary Hospital, Federal University of Mato Grosso, \\ Av. Fernando Correa da Costa 2367, Cuiabá 78090-900, Brazil; sayhatum@gmail.com \\ * Correspondence: danmoura@ufmt.br; Tel.: +55-65-3615-8662
}

Received: 28 September 2020; Accepted: 28 October 2020; Published: 29 October 2020

\begin{abstract}
Tandem repeat proteins (TRPs) are major immunoreactive proteins of Ehrlichia canis, which have been used in the serological diagnosis of different genotypes of the microorganism. TRP19 is preserved among different $E$. canis isolates expressed on both reticulate and dense-core cells and observed in the extracellular matrix or associated with the morula membrane. TRP36 is differentially expressed only on the surface of the dense-core form of the bacterium and exhibits more divergence among isolates. The aim of this study was to evaluate the distribution of the American (USTRP36), Brazilian (BrTRP36) and Costa Rican (CRTRP36) genotypes of E. canis in Brazil, using ELISA assays. Serum samples of 814 dogs from 49 municipalities from all over Brazil were analyzed. Our results showed that $34 \%$ of the samples were reactive to the USTRP36 genotype and 32.6\% to the BrTRP36 genotype. The two genotypes appeared to occur equally throughout Brazil, although the frequency of seropositivity was lower in the south than in the country's other regions. Dogs that reacted to at least one of the synthetic peptides (TRP19 and TRP36) were 456 (56\%). A few dogs $(n=5 ; 0.61 \%)$ reactive to the E. canis TRP36 genotype (CRTRP36) were also detected in the northeast and southern regions. We concluded that the American and Brazilian genotypes of E. canis are distributed evenly in Brazil, especially in the tropical region, while the temperate region in the south presented the lowest prevalence rates. This study offers the first report of dogs seropositive for the Costa Rican genotype in Brazil.
\end{abstract}

Keywords: dogs; ehrlichiosis; ELISA; tick-borne; TRP36; TRP19

\section{Introduction}

Ehrlichia canis is the etiologic agent of canine monocytic ehrlichiosis (CME), a serious tick-borne disease of worldwide distribution [1]. A group of tandem repeat proteins of 19 and $36 \mathrm{kDa}$ (TRP19 and TRP36) were characterized as important immunoreactive proteins of E. canis and were employed in the serological diagnosis of CME [2,3].

TRP19 is highly conserved among the known E. canis strains and was found on both reticulate and dense-core cells. Although they appeared to be located predominantly in the cytoplasm of Ehrlichia, they also appeared to be present outside the morula, suggesting that they may be involved in host cell interactions during infection. TRP19 is a specific target for serological diagnostics [3-6] and a strong candidate for vaccine antigen against $\mathrm{CME}$, due to its high degree of conservation and because it is a component of the morula membrane [7]. 
TRP36 provides more information about the genetic diversity of E. canis due to the divergence within amino acid tandem repeat sequences and/or in the number of tandem repeats [6,8-10]. The TRP36 protein is secreted by E. canis at the time of intracellular colonization and because it is involved in the adaptive process between the microorganism and the host, it has vaccine potential [3]. Ehrlichia canis TRP36 synthetic peptide antigens were used in enzyme-linked immunosorbent assays (ELISA) by Aguiar et al. [4], who found dogs seroreactive to two distinct genotypes in Brazil: American (USTRP36) and Brazilian (BrTRP36). Recently, dogs seropositive to the new zoonotic E. canis TRP36 genotype described in Costa Rica (CRTRP36) were identified in Colombia [9,11].

In view of the epidemiological importance of CME in Brazil, and the antigenic relevance of these proteins, canine blood samples were obtained from various regions of Brazil to be evaluated in serological assays using crude E. canis antigens by immunofluorescence assay (IFA) and synthetic peptides from TRP19 and 36 (American, Brazilian and Costa Rican genotypes) by ELISA. Moreover, the use of TRP36 antigens revealed the wide distribution of different genotypes throughout Brazil and the first report of dogs seropositive for the Costa Rican genotype in Brazil.

\section{Materials and Methods}

This study included serum samples from 814 dogs suspected of CME in 49 municipalities (Tables 1 and 2) all over Brazil and treated at veterinary clinics and hospitals and zoonosis control centers. Canine serum samples from the city of Palotina, in the state of Paraná $(n=30)$ were previously selected and analyzed, since one of them was known to be E. canis positive (SNAP 4Dx ${ }^{\circledR}$ Plus Test IDEXX Laboratories@) , Westbrook, Maine). The presence of anti-Ehrlichia spp. serum antibodies was determined by IFA, using crude antigens of the Cuiaba\#1 strain of E. canis [12]. ELISA was performed with synthetic peptides corresponding to epitopes from E. canis TRP19 (HFTGPTSFEVNLSEEEKMELQEVS) [7], USTRP36 (TEDSVSAPATEDSVSAPA) [3], BrTRP36 (ASVVPEAEASVVPEAEASVVPEAE) [4] and CRTRP36 (EASVVPAAEAPQPAQQTEDEFFSDGIEA) [11]. All the ELISA assays were performed according to a previously described protocol [4,5]. Differences between the results found per region and E. canis TRP36 peptides were evaluated by the chi-square test and $p \leq 0.05$ was considered significant. The statistical analysis was performed using Epi Info ${ }^{\mathrm{TM}}$ version 5.5.1 software. This study was approved by the Committee on Animal Research and Ethics of the Federal University of Mato Grosso (UFMT) under protocol no. 23108.122592/2015-10.

\section{Results}

The average number of samples evaluated per city was 14.5 in the center west, 13 in the northeast, 15.25 in the north, 15.3 in the southeast and 28.8 in the south. Tables 1 and 2 list the number of dogs tested and seropositive in serological assays per city and region. A total of $349(42.8 \%)$ dogs had antibodies to the TRP19 peptide, 277 (34\%) had antibodies to the USTRP36 peptide, 266 (32.6\%) had antibodies to the BrTRP36 peptide and $5(0.61 \%)$ dogs had antibodies to the CRTRP36 peptide. Dogs that reacted to at least one of the synthetic peptides (TRP19 and TRP36) were 456 (56\%). Dual reactivity in dogs positive for USTRP36 and BrTRP36 peptides was detected in 131 samples $(16.0 \%)$ from all the regions. The frequency of seropositivity for any of the TRP36 peptides was 50.7\% (413/814). Reactive solely to TRP19 were $40(4.9 \%)$ and to TRP36 were 104 (12.7\%). Three hundred and seventy-five (46\%) dogs were seroreactive to IFA. Overall, similar results were observed among the dogs reactive to USTRP36 and BrTRP36 in all the Brazilian regions $(p>0.05)$ (uppercase letters in Table 2). However, the values showed differences when evaluated as a function of antigen (lowercase letters in Table 2). The southern region, for example, differed from the others in all the tests $(p<0.05)$. Exceptionally, samples from Barra do Quaraí and Curitiba were negative for IFA, and all the peptides and reactions against CR TRP36 peptides were observed only in Aracaju, SE and Londrina, PR. Figure 1 shows the location of each city and the ELISA results using TRP36 synthetic peptides. 
Table 1. Number of sampled and positive dogs in serological assays by city and region in Brazil.

\begin{tabular}{|c|c|c|c|c|c|c|c|}
\hline \multirow{2}{*}{ Location * } & \multirow{2}{*}{$\begin{array}{c}\text { Map } \\
\text { Reference }\end{array}$} & \multirow{2}{*}{$\begin{array}{l}\text { No. of } \\
\text { Dogs }\end{array}$} & \multicolumn{4}{|c|}{ ELISA (\%) } & \multirow{2}{*}{$\begin{array}{c}\text { IFA } \\
\text { (Immunofluorescence Assay) (\%) }\end{array}$} \\
\hline & & & TRP19 & USTRP36 & BrTRP36 & CRTRP36 & \\
\hline North & & 122 & $65(53.2)$ & $38(31.1)$ & $45(36.8)$ & 0 & $58(47.5)$ \\
\hline Porto Velho, RO & 1 & 15 & 11 & 7 & 5 & 0 & 9 \\
\hline Cacoal, RO & 2 & 15 & 8 & 2 & 6 & 0 & 8 \\
\hline Brasiléia, AC & 3 & 13 & 8 & 4 & 4 & 0 & 6 \\
\hline Rio Branco, AC & 4 & 16 & 9 & 3 & 3 & 0 & 10 \\
\hline Boa Vista, RR & 5 & 18 & 14 & 13 & 15 & 0 & 12 \\
\hline Belém, PA & 6 & 16 & 5 & 2 & 6 & 0 & 4 \\
\hline Macapá, AP & 7 & 15 & 4 & 4 & 3 & 0 & 3 \\
\hline Araguaína, TO & 8 & 14 & 6 & 3 & 3 & 0 & 6 \\
\hline Northeast & & 236 & $114(48.3)$ & $111(47.0)$ & $94(39.8)$ & $3(1.27)$ & $124(52.5)$ \\
\hline São Luís, MA & 9 & 18 & 7 & 4 & 6 & 0 & 4 \\
\hline Balsas, MA & 10 & 9 & 1 & 0 & 1 & 0 & 1 \\
\hline Bacabal, MA & 11 & 10 & 4 & 2 & 4 & 0 & 4 \\
\hline Raposa, MA & 12 & 12 & 5 & 3 & 6 & 0 & 7 \\
\hline Guaribas, PI & 13 & 14 & 8 & 9 & 7 & 0 & 9 \\
\hline Crato, CE & 14 & 15 & 9 & 8 & 5 & 0 & 10 \\
\hline Mossoró, RN & 15 & 14 & 7 & 2 & 7 & 0 & 8 \\
\hline João Pessoa, PB & 16 & 14 & 5 & 8 & 6 & 0 & 7 \\
\hline Campina Grande, PB & 17 & 10 & 4 & 1 & 3 & 0 & 3 \\
\hline Petrolina, PE & 18 & 15 & 11 & 13 & 8 & 0 & 15 \\
\hline Serrita, PE & 19 & 15 & 6 & 11 & 10 & 0 & 11 \\
\hline Lagoa Grande, PE & 20 & 15 & 8 & 10 & 4 & 0 & 8 \\
\hline Salgueiro, PE & 21 & 20 & 3 & 11 & 2 & 0 & 2 \\
\hline Maceió, AL & 22 & 15 & 13 & 6 & 10 & 0 & 10 \\
\hline Cruz das Almas, BA & 23 & 10 & 6 & 9 & 8 & 0 & 9 \\
\hline Salvador, BA & 24 & 15 & 9 & 5 & 6 & 0 & 8 \\
\hline Aracaju, SE & 25 & 15 & 8 & 9 & 1 & 3 & 8 \\
\hline Central West & & 131 & $75(57.2)$ & $58(44.2)$ & $51(38.9)$ & 0 & $87(66.4)$ \\
\hline Cuiabá, MT & 26 & 15 & 15 & 10 & 5 & 0 & 15 \\
\hline Barra do Garças, MT & 27 & 15 & 13 & 10 & 10 & 0 & 13 \\
\hline Colniza, MT & 28 & 15 & 11 & 11 & 6 & 0 & 11 \\
\hline Campo Grande, MS & 29 & 15 & 9 & 6 & 8 & 0 & 9 \\
\hline Dourados, MS & 30 & 15 & 7 & 1 & 5 & 0 & 12 \\
\hline Jataí, GO & 31 & 15 & 8 & 7 & 10 & 0 & 12 \\
\hline Mineiros, GO & 32 & 15 & 4 & 6 & 2 & 0 & 7 \\
\hline Goiânia GO & 33 & 11 & 5 & 2 & 3 & 0 & 5 \\
\hline Brasília, DF & 34 & 15 & 3 & 5 & 2 & 0 & 3 \\
\hline Southeast & & 123 & $62(50.4)$ & $43(34.9)$ & $54(43.9)$ & 0 & $66(53.6)$ \\
\hline Uberlândia, MG & 35 & 17 & 11 & 13 & 8 & 0 & 13 \\
\hline Itabirito, MG & 36 & 16 & 4 & 2 & 5 & 0 & 4 \\
\hline Niterói, RJ & 37 & 15 & 6 & 5 & 5 & 0 & 6 \\
\hline Seropédica, RJ & 38 & 15 & 9 & 7 & 5 & 0 & 8 \\
\hline Vitória, ES & 39 & 19 & 7 & 3 & 10 & 0 & 9 \\
\hline Botucatu, SP & 40 & 15 & 12 & 3 & 8 & 0 & 15 \\
\hline São Paulo, SP & 41 & 15 & 7 & 4 & 7 & 0 & 4 \\
\hline Pres. Prudente, SP & 42 & 11 & 6 & 6 & 6 & 0 & 7 \\
\hline South & & 202 & $33(16.3)$ & $27(13.3)$ & $22(10.8)$ & $2(0.9)$ & $40(19.8)$ \\
\hline Joinville, SC & 43 & 30 & 1 & 4 & 3 & 0 & 4 \\
\hline Concórdia, SC & 44 & 40 & 2 & 0 & 2 & 0 & 1 \\
\hline Londrina, PR & 45 & 14 & 5 & 3 & 2 & 2 & 6 \\
\hline Palotina, PR & 46 & 30 & 25 & 19 & 14 & 0 & 27 \\
\hline Curitiba, PR & 47 & 28 & 0 & 0 & 0 & 0 & 0 \\
\hline Porto Alegre, RS & 48 & 30 & 0 & 1 & 1 & 0 & 2 \\
\hline Barra do Quaraí, RS & 49 & 30 & 0 & 0 & 0 & 0 & 0 \\
\hline Total & & 814 & $349(42.8)$ & $277(34)$ & $266(32.6)$ & $5(0.61)$ & $375(46)$ \\
\hline
\end{tabular}

* AC-Acre, AL-Alagoas, AP-Amapá, BA-Bahia, CE-Ceará, DF-Distrito Federal, ES-Espirito Santo, GO-Goiás, MA-Maranhão, MG-Minas Gerais, MS-Mato Grosso do Sul, MT-Mato Grosso, PA-Pará, PB-Paraíba, PE—Pernambuco, PR—Paraná, RJ—Rio de Janeiro, RN—Rio Grande do Norte, RO-Rondônia, RR—Roraima, RS—Rio Grande do Sul, SC—Santa Catarina, SE—Sergipe, SP—São Paulo, TO—Tocantins. 
Table 2. Number and frequency of seropositive dogs according to serological assays, average and range of optical density by Tandem repeat proteins (TRPs) ELISA and titer range in IFA.

\begin{tabular}{|c|c|c|c|c|c|c|}
\hline \multirow[t]{2}{*}{ Region } & \multirow[t]{2}{*}{ No. of Dogs } & \multicolumn{4}{|c|}{$\begin{array}{l}\text { Number of Positive Dogs (Frequency) } \\
\text { (Optical Density Average; Range) }\end{array}$} & \multirow{2}{*}{$\begin{array}{l}\text { IFA (Frequency) } \\
\text { (Titer Ranging) }\end{array}$} \\
\hline & & TRP19 & USTRP36 * & BrTRP36 * & CRTRP36 & \\
\hline North & 122 & $\begin{array}{c}65(53.2 \%) \mathrm{a} \\
(2.25 ; 0.42-3.77)\end{array}$ & $\begin{array}{l}38(31.1 \%) \text { A b } \\
(1.21 ; 0.33-3.58)\end{array}$ & $\begin{array}{l}45(36.8 \%) \mathrm{A} \mathrm{a} \\
(1.8 ; 0.33-3.8)\end{array}$ & 0 & $\begin{array}{l}58(47.5 \%) \mathrm{c} \mathrm{b} \\
(40 \text { to } 10,240)\end{array}$ \\
\hline Northeast & 236 & $\begin{array}{c}114(48.3 \%) \mathrm{a} \\
(2.05 ; 0.39-3.80)\end{array}$ & $\begin{array}{l}111(47.0 \%) \text { A a } \\
(1.48 ; 0.33-3.47)\end{array}$ & $\begin{array}{c}94(39.8 \%) \mathrm{A} \text { a } \\
(2.06 ; 0.33-4.02)\end{array}$ & $\begin{array}{c}3(1.27 \%) \\
(1.6 ; 1.04-2.13)\end{array}$ & $\begin{array}{l}124(52.5 \%) b \\
(40 \text { to } 10,240)\end{array}$ \\
\hline Center West & 131 & $\begin{array}{c}75(57.2 \%) \mathrm{a} \\
(2.22 ; 0.34-3.9)\end{array}$ & $\begin{array}{c}58(44.2 \%) \mathrm{A} \mathrm{a} \\
(1.63 ; 0.33-3.24)\end{array}$ & $\begin{array}{c}51(38.9 \%) \mathrm{A} \mathrm{a} \\
(1.82 ; 0.33-4.02)\end{array}$ & $0(0 \%)$ & $\begin{array}{c}87(66.4 \%) \text { a } \\
(40 \text { to } 10,240)\end{array}$ \\
\hline Southeast & 123 & $\begin{array}{c}62(50.4 \%) \mathrm{a} \\
(2.01 ; 0.35-3.74) \\
\end{array}$ & $\begin{array}{l}43(34.9 \%) \text { A b } \\
(1.45 ; 0.37-3.3)\end{array}$ & $\begin{array}{c}54(43.9 \%) \mathrm{A} \mathrm{a} \\
(1.72 ; 0.36-3.96)\end{array}$ & 0 & $\begin{array}{c}66(53.6 \%) b \\
(40 \text { to } 10,240)\end{array}$ \\
\hline South & 202 & $\begin{array}{c}33(16.3 \%) b \\
(2.33 ; 0.37-3.95) \\
\end{array}$ & $\begin{array}{c}27(13.3 \%) \text { A c } \\
(0.78 ; 0.33-2.51)\end{array}$ & $\begin{array}{l}22(10.8 \%) \text { A b } \\
(1.6 ; 0.33-3.65)\end{array}$ & $\begin{array}{c}2(0.9 \%) \\
(0.5 ; 0.35-0.66)\end{array}$ & $\begin{array}{c}40(19.8 \%) \mathrm{d} \\
(40 \text { to } 10,240)\end{array}$ \\
\hline TOTAL & 814 & $\begin{array}{c}349(42.8 \%) \\
(2.17 ; 0.34-3.95)\end{array}$ & $\begin{array}{c}277(34.0 \%) \mathrm{A} \\
(1.51 ; 0.33-3.58)\end{array}$ & $\begin{array}{l}266(32.6 \%) \mathrm{A} \\
(1.8 ; 0.33-4.02)\end{array}$ & $\begin{array}{c}5(0.61 \%) \\
(1.05 ; 0.35-2.13)\end{array}$ & $\begin{array}{c}375(46 \%) \\
(40 \text { to } 10,240)\end{array}$ \\
\hline
\end{tabular}

* Same upperc
$(p<0.05)$. 


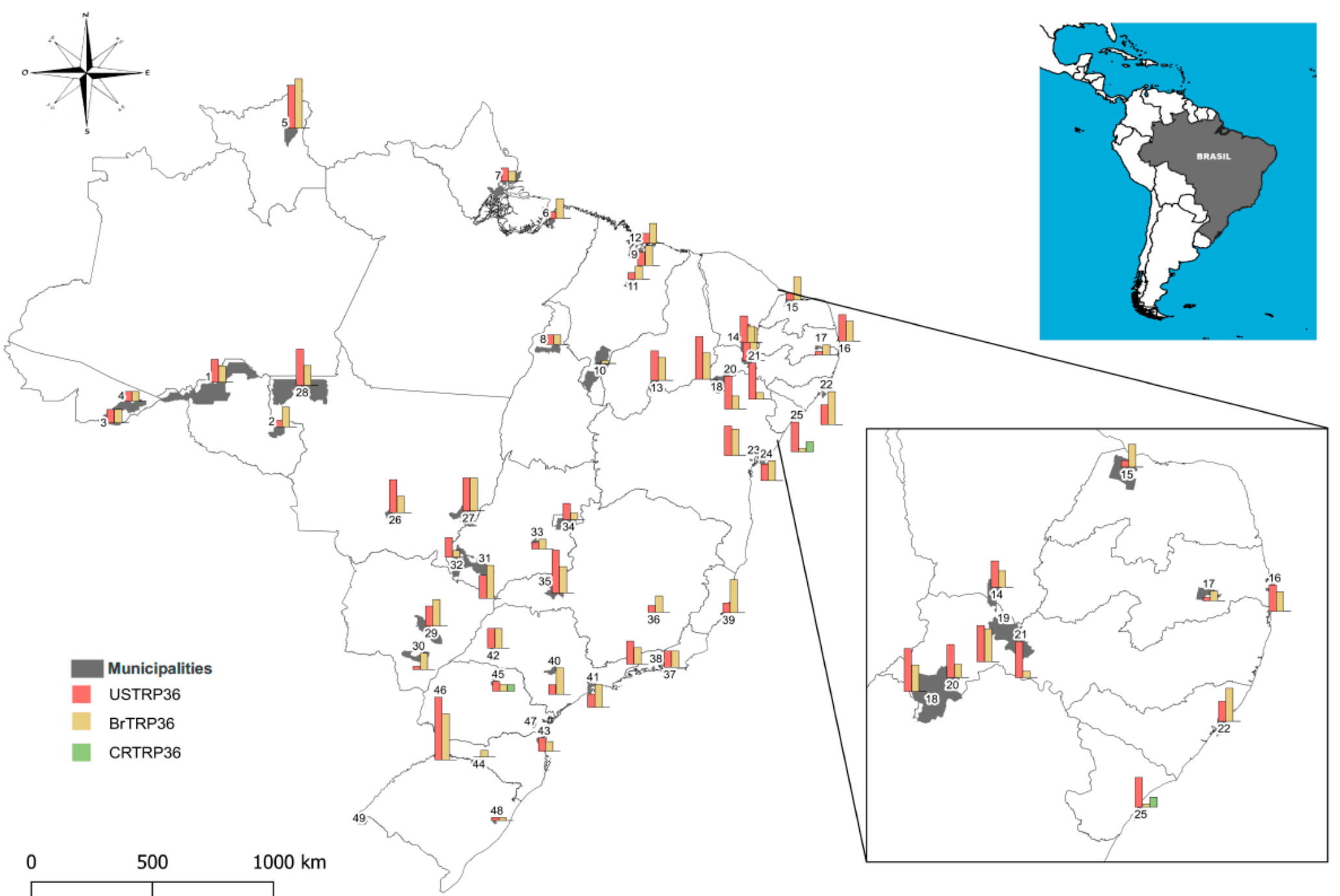

Figure 1. Distribution of E. canis genotypes in Brazil. 


\section{Discussion}

The present study involved a serological survey in dogs from all over Brazil, based on the detection of antibodies against antigens of E. canis TRPs. Taking into account dogs that reacted against any of E. canis TRP synthetic peptides, the frequency observed was $56 \%$. This value exceeded the result observed in the E. canis-IFA, which was $46 \%$. A previous study provided a higher level of sensitivity when recombinant TRP19/36 E. canis proteins in an ELISA format was used compared to E. canis-IFA during the early stages of canine ehrlichiosis [2]. Dogs that reacted to at least one of the TRP36 peptides had a higher frequency of positivity than those that were positive for TRP19. This result was expected because experimentally infected dogs showed earlier reactivity to TRP36 than TRP19 [2].

In Brazil, with the exception of the southern states of Santa Catarina and Rio Grande do Sul [13], Ehrlichia canis infections in dogs are widespread around the country, showing high prevalence rates and high IFA titers [14]. Our study is the first to assess the distribution of E. canis genotypes based on the detection of specific antibodies against $E$. canis TRP36 synthetic peptides in dogs suspected of CME from all over Brazil. Our findings indicated that the American and Brazilian genotypes are widely distributed throughout the country's various regions (Figure 1).

The presence of co-reaction between US and Br genotypes, suggestive of co-infection by the different TRP36 genotypes, was identified in all the regions. Co-infection by different genotypes in the same host may lead to the development of the genetic recombination of E. canis. This mechanism is commonly used by microorganisms as an immune evasion strategy and is also considered a major driver of genetic diversity in obligate intracellular microorganisms [15]. Examples of this phenomenon are reported in the isolate Cuiabá \#16 of E. canis and several isolates of E. ruminantium [8,16]. As seen in other tick-borne pathogens [15], the genetic recombination process can generate new strains of E. canis with different degrees of virulence, which may be fatal to dogs. Furthermore, new strains may be able to infect and adapt to new hosts, as probably occurred with E. canis and E. minasensis in bovines [17].

Unfortunately, our study was limited to testing dogs suspected of CME. Complete clinical data of the dogs in this study were not available for reasons of medical confidentiality. No clinical differences between US or Br genotypes were observed in a hospital population of dogs suffering from CME in an endemic area in Brazil [5], while clinical differences were observed in dogs infected by different genotypes in another study [18]. To date, the genetic diversity may be related to the host-pathogen relationship. In this regard, a larger number of clinical cases of CME should be investigated in order to ensure more reliable conclusions about the clinical diseases and infections by different genotypes of E. canis in dogs.

Indeed, the fairly large number of co-infected dogs detected in Brazil supports the possibility of the emergence of new genotypes of E. canis. In our study, 40 (4.9\%) dogs reactive only to TRP19 peptide suggests that these dogs may have been exposed to a to date undescribed E. canis TRP36 genotype circulating in Brazil.

Despite the low detection of antibodies against the Costa Rica genotype in our study $(n=5 ; 0.61 \%)$, this genotype may also have been a target of genetic recombination, since its amino acid sequence is similar to that of BrTRP36 [9,18]. In Brazil, this genotype was found pointwise in Aracajú-northeast region (three dogs) and Londrina-south region (two dogs). The genotype CRTRP36 was first detected in the blood of human donors in Costa Rica, exhibiting a potential zoonotic relationship [9]. However, data from South American serosurveys reveal evidence of infection by this genotype only in dogs from Colombia and Peru [11,19].

Our findings confirmed the low occurrence of seroreactive dogs in the south of Brazil. Similar data have been reported but are based only on the IFA test [13]. In the present study, with the exception of samples from the city of Palotina, PR, the other samples showed IFA results ( 7.5\%; 13/172 samples) similar to those reported [13]. However, $15 \%(2 / 13)$ of these samples presented seronegative results in all the ELISA assays using synthetic peptides of E. canis. This suggests that some of the reactions observed in dogs by IFA in the south are nonspecific, probably reflecting cross-reactions produced during antigenic stimulation after infections by closely related agents such as $A$. platys or unknown 
Ehrlichia species [20]. It should be noted that a relevant factor influencing the low prevalence of E. canis infection in the south of Brazil is the presence of the temperate strain of $R$. sanguineus ticks established in the region, which has low vector competence for the agent [21].

\section{Conclusions}

We conclude, from this study, that E. canis genotypes based on the TRP36 protein are distributed equally throughout Brazil. Comparisons between IFA and ELISA TRP19 reveal the occurrence of false positive reactions resulting from cross-reactions with other agents similar to E. canis in the indirect immunofluorescence reaction. Brazil's southern region has lower rates of seropositive dogs than other Brazilian regions. This paper reports for the first time dogs seropositive for the Costa Rican genotype of E. canis in Brazil.

Author Contributions: Conceptualization, I.I.G.G.T. and D.M.d.A.; methodology, D.M.d.A.; formal analysis, I.I.G.G.T., A.N.S.C., M.L.K., S.L.H.d.A.; investigation, I.I.G.G.T., A.N.S.C., M.L.K., S.L.H.d.A.; resources, D.M.d.A.; data curation, I.I.G.G.T.; writing — original draft preparation, I.I.G.G.T., D.M.d.A.; writing-review and editing, I.I.G.G.T., D.M.d.A.; supervision, D.M.d.A.; project administration, D.M.d.A.; funding acquisition, D.M.d.A. All the authors have read and agreed to the published version of the manuscript. All authors have read and agreed to the published version of the manuscript.

Funding: This research was funded by Brazil's National Council for Scientific and Technological Development (CNPq), grant number 443923/2014-0.

Acknowledgments: We thank all our fellow veterinarians who contributed to this research by donating blood samples for analysis, namely, Ana C.D.S. Bezerra, Ana R.A. Ribeiro, André M.C. Meneses, Andréia Borges, Antônio C. Paes, Antônio V. Mundim, Camila V. Bastos, Carla J.R.M. Rosário, Carlos A.N. Ramos, Chayana F. Chaim, Cristiane D. Baldani, Felipe S. Krawazak, Fernanda T. Vieira, Fernando Bastos, Flávio H.B. Caldeira, Giane R. Paludo, Ísis A. Braga, Izabelle T.S. Carvalho, João F. Soares, Jonas M. Filho, José N. Silva, Kledir A.H. Spohr, Luis F.P. Gondim, Maerle O. Maia, Maira M.C. Freitas, Make K. Minetto, Marcelo Zanutto, Maurício C. Horta, Odinei Ferranti, Paula G. S. Baggio, Rita M. Neves, Sergio S. Azevedo, Silvia C. Osaki, Soraya R. S. Surian, and Vamilton A. Santarém. We thank DVM Ana C. Schmidt for her technical support with map construction. We are also indebted to Brazil's Federal Agency for the Support and Improvement of Higher Education (CAPES) for scholarships granted to I.I.G.G. Taques, A.N.S. Campos, M.L. Kavasaki and S.L.H. Almeida and to CNPq for a research productivity grant awarded to D.M. Aguiar (grant 303677/2018-0). D.M. Aguiar thanks God for his life and for his work in veterinary medicine.

Conflicts of Interest: The authors declare no conflict of interest.

\section{References}

1. Zweygarth, E.; Cabezas-Cruz, A.; Josemans, A.I.; Oosthuizen, M.C.; Matjila, P.T.; Lis, K.; Broniszewska, M.; Schöl, H.; Ferrolho, J.; Grubhoffer, L.; et al. In vitro culture and structural differences in the major immunoreactive protein gp36 of geographically distant Ehrlichia canis isolates. Ticks Tick Borne Dis. 2014, 5, 423-431. [CrossRef]

2. Cárdenas, A.M.; Doyle, K.; Zhang, X.; Nethery, K.; Corstvet, R.E.; Walker, D.H.; McBride, J.W. Enzyme-Linked Immunosorbent Assay with Conserved Immunoreactive Glycoproteins gp36 and gp19 Has Enhanced Sensitivity and Provides Species-Specific Immunodiagnosis of Ehrlichia canis Infection. Clin. Vaccine Immunol. 2007, 14, 123-128. [CrossRef] [PubMed]

3. Doyle, C.K.; Nethery, K.A.; Popov, V.L.; McBride, J.W. Differentially Expressed and Secreted Major Immunoreactive Protein Orthologs of Ehrlichia canis and E. chaffeensis Elicit Early Antibody Responses to Epitopes on Glycosylated Tandem Repeats. Infect. Immun. 2006, 74, 711-720. [CrossRef] [PubMed]

4. Aguiar, D.M.; Zhang, X.; Braga, I.A.; Taques, I.I.G.G.; McBride, J.W. Detection of genotype-specific Ehrlichia canis exposure in Brazilian dogs by TRP36 peptide ELISA. Ticks Tick-Borne Dis. 2016, 7, 142-145. [CrossRef] [PubMed]

5. Taques, I.I.G.G.; Koiyama, M.F.G.; Campos, A.N.S.; Costa, J.S.; Hongyu, K.; Aguiar, D.M. Canonical correlation analysis between the ELISA assay using synthetic peptides, the indirect fluorescent antibody test and hematology values in dogs infected with Ehrlichia canis. Vet. Clin. Pathol 2020, in press. [CrossRef] 
6. Zhang, X.; Luo, T.; Keysary, A.; Baneth, G.; Miyashiro, S.; Strenger, C.; Waner, T.; McBride, J.W. Genetic and Antigenic Diversities of Major Immunoreactive Proteins in Globally Distributed Ehrlichia canis Strains. Clin. Vaccine Immunol. 2008, 15, 1080-1088. [CrossRef] [PubMed]

7. McBride, J.W.; Doyle, C.K.; Zhang, X.; Cárdenas, A.M.; Popov, V.L.; Nethery, K.A.; Woods, M.E. Identification of a Glycosylated Ehrlichia canis 19-Kilodalton Major Immunoreactive Protein with a Species-Specific Serine-Rich Glycopeptide Epitope. Infect. Immun. 2007, 75, 74-82. [CrossRef]

8. Aguiar, D.M.; Zhang, X.; Melo, A.L.T.; Pacheco, T.A.; Meneses, A.M.C.; Zanutto, M.S.; Horta, M.C.; Santarém, V.A.; Camargo, L.M.A.; McBride, J.W.; et al. Genetic diversity of Ehrlichia canis in Brazil. Vet. Microbiol. 2013, 164, 315-321. [CrossRef]

9. Bouza-Mora, L.; Dolza, G.; Solórzano-Morales, A.; Romero-Zuñigaa, J.J.; Salazar-Sánchez, L.; Labruna, M.B.; Aguiar, D.M. Novel genotype of Ehrlichia canis detected in samples of human blood bank donors in Costa Rica. Ticks Tick Borne Dis. 2017, 8, 36-40. [CrossRef]

10. Doyle, C.K.; Cárdenas, A.M.; Aguiar, D.M.; Labruna, M.B.; Ndip, L.M.; Yu, X.; Mcbride, J.W. Molecular Characterization of E. canis gp36 and E. chaffeensis gp47 Tandem Repeats among Isolates from Different Geographic Locations. Ann. N. Y. Acad. Sci. 2005, 1063, 433-435. [CrossRef]

11. Arroyave, E.; Rodas-González, J.D.; Zhang, X.; Labruna, M.B.; González, M.S.; Fernández-Silva, J.A.; McBride, J.W. Ehrlichia canis TRP36 diversity in naturally infected dogs from an urban area of Colombia. Ticks Tick Borne Dis. 2020, 11, 101367. [CrossRef]

12. Aguiar, D.M.; Saito, T.B.; Hagiwara, M.K.; Machado, R.Z.; Labruna, M.B. Diagnóstico sorológico de erliquiose canina com antígeno brasileiro de Ehrlichia canis. Ciênc. Rural 2007, 37, 796-802. [CrossRef]

13. Saito, T.B.; Cunha-Filho, N.A.; Pacheco, R.C.; Ferreira, F.; Pappen, F.G.; Farias, N.A.R.; Larsson, C.E.; Labruna, M.B. Canine Infection by Rickettsiae and Ehrlichiae in Southern Brazil. Am. J. Trop. Med. Hyg. 2008, 70, 102-108. [CrossRef]

14. Vieira, R.F.C.; Biondo, A.W.; Guimarães, A.M.S.; Santos, A.P.; Santos, R.P.; Leonardo Hermes Dutra, L.H.; Diniz, P.P.V.P.; Morais, H.A.; Joanne Belle Messick, J.B.; Labruna, M.B.; et al. Ehrlichiosis in Brazil. Braz. J. Vet. Parasitol. 2011, 20, 1-12. [CrossRef] [PubMed]

15. Palmer, G.H.; Bankhead, T.; Seifert, H.S. Antigenic Variation in Bacterial Pathogens. Microbiol. Spectr. $2016,4$. [CrossRef]

16. Allsopp, M.T.E.P.; Allsopp, B.A. Extensive genetic recombination occurs in the field between different genotypes of Ehrlichia ruminantium. Vet. Microbiol. 2007, 124, 58-65. [CrossRef]

17. Cabezas-Cruz, A.; Valdés, J.J.; de la Fuente, J. The glycoprotein TRP36 of Ehrlichia sp. UFMG-EV and related cattle pathogen Ehrlichia sp. UFMT-BV evolved from a highly variable clade of $E$. canis under adaptive diversifying selection. Parasites Vectors 2014, 7, 584. [CrossRef]

18. Ferreira, R.F.; Cerqueira, A.M.F.; Castro, T.X.; Ferreira, E.O.; Neves, F.P.G.; Barbosa, A.V.; Macieira, D.B.; Almosny, N.R.P. Genetic diversity of Ehrlichia canis strains from naturally infected dogs in Rio de Janeiro, Brazil. Braz. J. Vet. Parasitol. 2014, 23, 301-308. [CrossRef] [PubMed]

19. Geiger, J.; Morton, B.A.; Vasconcelos, E.J.R.; Tngrian, M.; Kachani, M.; Barrón, E.A.; Gavidia, C.M.; Gilman, R.H.; Angulo, N.P.; Lerner, R.; et al. Molecular Characterization of Tandem Repeat Protein 36 Gene of Ehrlichia canis Detected in Naturally Infected Dogs from Peru. Am. J. Trop. Med. Hyg. 2018, 99, $297-302$. [CrossRef] [PubMed]

20. Harrus, S.; Waner, T. Diagnosis of canine monocytotropic ehrlichiosis (Ehrlichia canis): An overview. Vet. J. 2011, 187, 292-296. [CrossRef]

21. Moraes-Filho, J.; Marcili, A.; Nieri-Bastos, F.A.; Richtzenhain, L.J.; Marcelo, B.; Labruna, M.B. Genetic analysis of ticks belonging to the Rhipicephalus sanguineus group in Latin America. Acta Trop. 2011, 117, 51-55. [CrossRef] [PubMed]

Publisher's Note: MDPI stays neutral with regard to jurisdictional claims in published maps and institutional affiliations. 